\title{
Corrigendum to "Topography Prediction of Helical Transmembrane Proteins by a New Modification of the Sliding Window Method"
}

\author{
Maria N. Simakova ${ }^{1}$ and Nikolai N. Simakov ${ }^{2}$ \\ ${ }^{1}$ A.F. Mozhaisky Military Space Academy, Yaroslavl 150001, Russia \\ ${ }^{2}$ Yaroslavl State Technical University, Yaroslavl 150023, Russia \\ Correspondence should be addressed to Maria N. Simakova; simakova.mary@gmail.com \\ Received 31 August 2017; Accepted 18 October 2017; Published 5 November 2017 \\ Copyright (c) 2017 Maria N. Simakova and Nikolai N. Simakov. This is an open access article distributed under the Creative \\ Commons Attribution License, which permits unrestricted use, distribution, and reproduction in any medium, provided the \\ original work is properly cited.
}

In the article titled "Topography Prediction of Helical Transmembrane Proteins by a New Modification of the Sliding Window Method" [1], the error occurred in formula (1): the summation index $i$ of the function $f_{n}(k+i)$ was accidentally lost. It should be corrected as follows:

$$
\begin{aligned}
& f_{n}(k)=\frac{1}{2 n+1} \sum_{i=-n}^{n} f_{n-1}(k+i), \quad n=1,2, \ldots, 5, \\
& f_{0}(k)=f(k) .
\end{aligned}
$$

\section{References}

[1] M. N. Simakova and N. N. Simakov, "Topography prediction of helical transmembrane proteins by a new modification of the sliding window method," BioMed Research International, vol. 2014, Article ID 921218, 9 pages, 2014. 

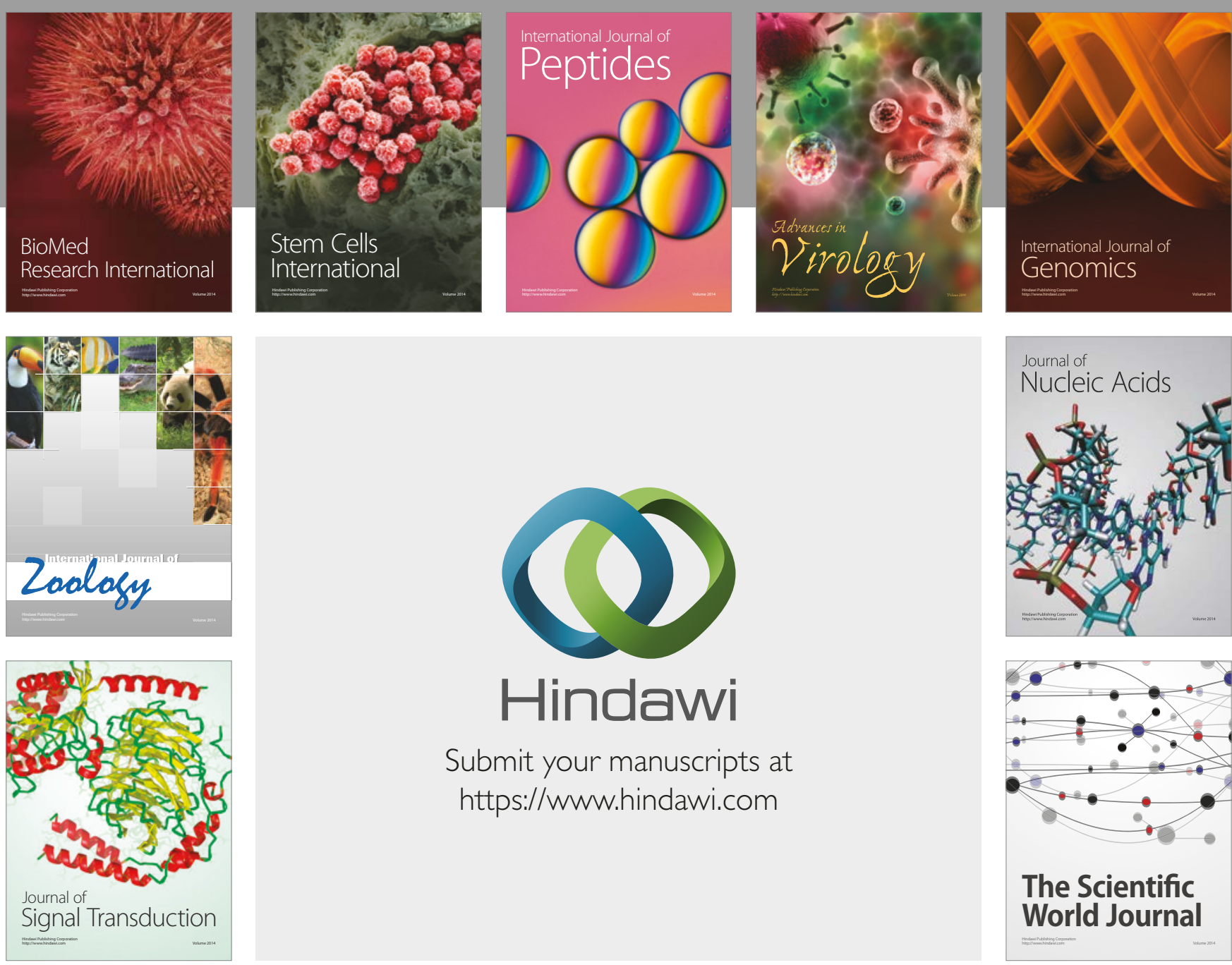

Submit your manuscripts at

https://www.hindawi.com
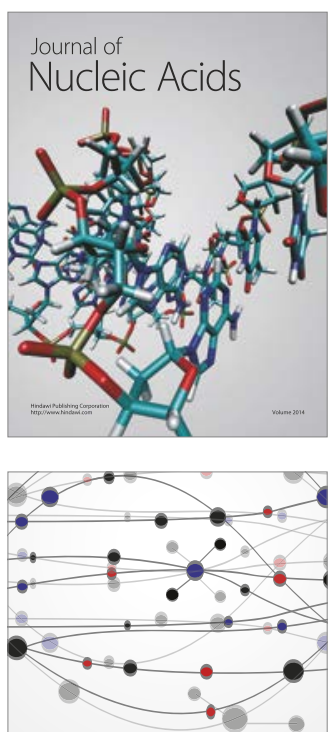

The Scientific World Journal

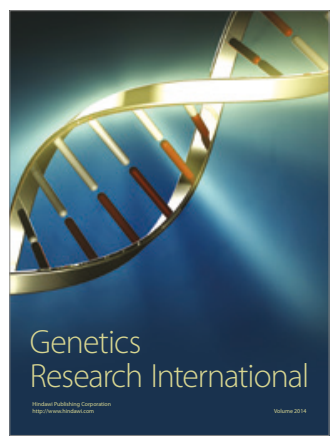

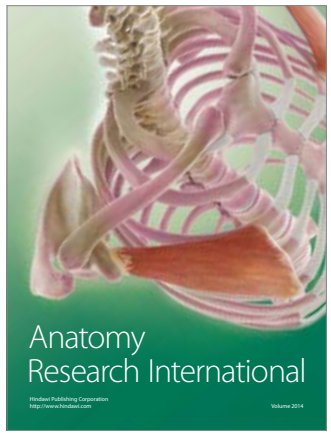

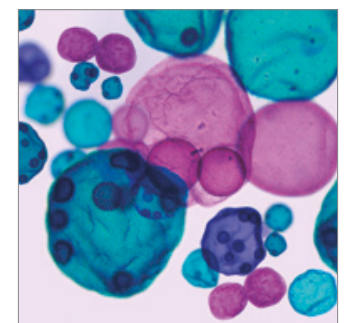

International Journal of Microbiology
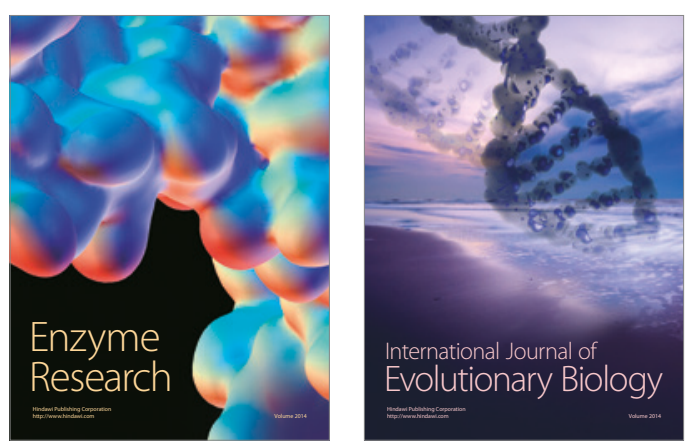
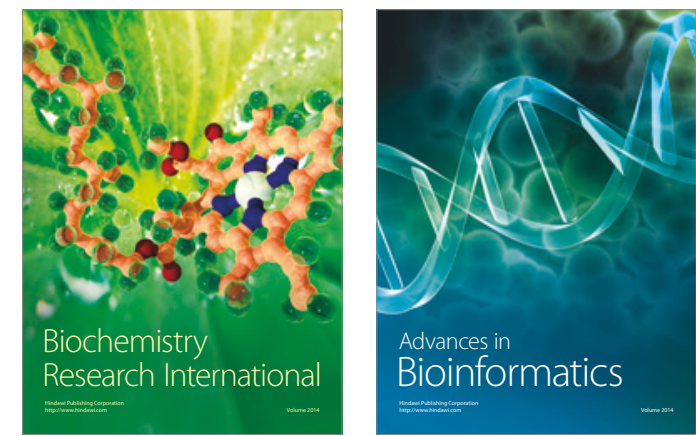

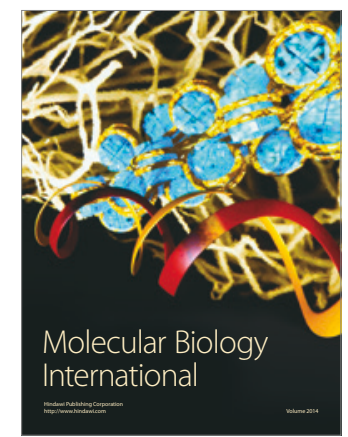

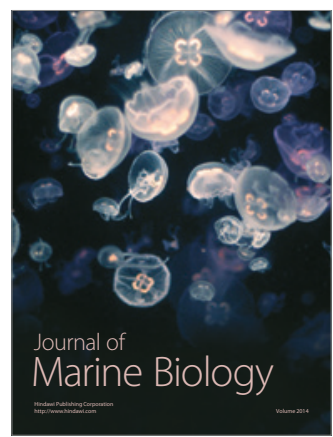

